\title{
Soil successions of Carbic Podzols (Arenic) under Scots Pine plantations in Kursk region
}

\author{
Nikolay Nevedrov*, Maria Fomina, and Galina Smitskaya \\ Kursk State University, 305000 Kursk, Russian Federation
}

\begin{abstract}
Anthropogenic activities lead to significant transformations of natural landscapes. In this article, an attempt was made to describe the soil succession in the context of 100-year dynamics of Scots Pine forest stand in Kursk region. The morphological, physical, chemical and physical and chemical characteristics of sandy podzols in the chronological order of pine forests functioning 0 - 70 - 100 years were under analysis. It was revealed that monodominant forest stand of Scots Pine leads to the transformation of soils at the type level. It is noted that forest stand of Scots Pine on Umbric Podzols contribute to the development of the podzolic process at an average rate of formation of the podzolic horizon - $0.11-0.17 \mathrm{sm} /$ year. During the time period of the soil succession (100 years), the thickness of the soil profile has increased and the humus reserves in the profile have increased by $47.1 \%$, as well as a total decrease in the content of mineral nutrients is noted. The content of mobile forms of heavy metals $(\mathrm{Cu}, \mathrm{Zn}, \mathrm{Ni}, \mathrm{Mn}$ and $\mathrm{Co})$ in the genetic horizons of Carbic Podzols (Arenic) in the time interval of the succession 70 - 100 years decreases by $21.4-71.4 \%$.
\end{abstract}

\section{Introduction}

Anthropogenic impact affects the change in the functioning of all natural mechanisms and influences natural processes in ecosystems and the biosphere as a whole. Science has accumulated a huge amount of knowledge about the transformation of agricultural soils (eolian erosion, rock erosion, trampling, soil salination, pollution, etc.), in particular in Central Black Soil region, starting with the works of V.V. Dokuchaev and ending with modern research[1], Ecological problems related to the genesis, evolution, succession, and degradation of the "King of Soils" - chernozem - have been studied in sufficient detail. A large number of works are devoted to the study of gray forest soils. Urban soils are also focus of attention of soil scientists and ecologists, the classification of urban soils was developed and introduced $[2,3,4]$. Sorption geochemical barriers and their peculiarities in connection with various types of soil pollution have been studied thoroughly $[5,6,7,8]$. The buffering capacity of various types of urban soils was evaluated, practical recommendations on environmental assessment and improving the soil stability, as well as optimization of soil services were developed $[9,10,11]$. Despite this, there is relatively little information regarding the long-term dynamic processes occurring in rare types of soils, under conditions of increased anthropogenic burden. A rare type of soil in the western part of the Central Black

\footnotetext{
* Corresponding author: 9202635354@mail.ru
} 
Soil region is illuvial and ferruterous sandy podzols, which occupy a relatively small fraction of the region's area. Most of them are found in terraces above flood-plain with dune relief, which are formed of ancient alluvial and fluvioglacial sands. The predominant vegetation is represented by uneven-aged pine forests. For example, man-made large plantations of common pine in the environ of Kursk in terraces above flood-plain of the river Seim (Gorely forest ecosite, Gutorev pine forest, Mokva ecosite, etc.) form the vast majority of the city's ecological framework [12, 13]. However, artificially planted pine forests are atypical communities for the Kursk regions (10\% of the afforestated area) and their characteristic feature is a connection with a certain stage of the succession series. The vegetation cover of pine forests is highly dependent on the topography and the amount of rainfall. In moisty topographic low of the pine forests, small-leaved and broad-leaved species (pedunculate oak, white birch, maple) and grassy representatives (sedge, cereal) can be observed. In dry, smoothed areas under dense canopy, the vegetation cover is extremely poorly developed. There is an abundance of dead cover areas, but lichens and green mosses are noted on relatively small areas [14].

The age and qualitative composition of plantations is a powerful driver that triggers the transformation of soil characteristics $[15,16]$, which affect the rest of the environment. Such transformations of natural and natural-anthropogenic landscapes subsequently affect the quality of the environment and economic activity, therefore, the direction and speed of soil successions of sandy podzols, functioning under intrazonal vegetation in conditions of increased spatial heterogeneity of the environment, requires detailed research. [13].

The aim of the work was to identify the speed and direction of successions of sandy podzols within the microperiod of pedogenesis 0 - 100 years (in Kursk region).

\section{Objects and methods of research}

Pine forests in Kursk and Kurchatov, as well as in their environs, perform a protective function, forming a green belt along the banks of the river Seim. In the cities themselves, they delimitate industrial and residential areas and play a recreational role. The research was carried out on the territory of the Gorely forest (key site 2 - pine forest stand about 70 years old) and a forest in the village of Dichnya near Kurchatov (key site 3 - pine forest stand about 100 years old). Before the Scots Pine forest stand appeared, the areas were covered with herbaceous (steppe) vegetation, which was established using the map of the General Staff of the Red Army in 1937 "Map of Europe and the European part of the USSR $\times 10 \mathrm{~km}$ " and the Schubert map of the late 19th century. A Umbric Podzol buried under a layer of technogenic surface formation (100 sm thick) on the territory of the liquidated plant of truck spare parts hereinafter KZTZ plant (key site 1) was taken as a zero moment. This is a profile preserved in 1954 (the year of foundation of the KZTZ plant), which may well reflect the morphology and partly the physical and chemical characteristics of steppe soils at the time of planting-out Scots pines (beginning of succession). Thick and dense layers of technosoils protected the buried Umbric Podzol from the influence of the vegetation cover, and poor aeration significantly reduced the activity of the microbiological soil complex. The sampling site was located on the second above flood-plain terrace of the right bank of the river Seim. Before the foundation of the plant, steppe vegetation was here. Thus, a chronological order of soil succession of Carbic Podzols (Arenic) can be analyzed when the steppe phytocenoses were replaced by plantations of Scots pine, followed by its vegetation $(0-70$ years - 100 years). Soil surveys were carried out on the key site 2 and key site 3(the Gorely forest tract, the forest area of the village of Dichnya); the soil profile cuts were carried out in the most typical conditions with the dominance of Scots pine of the required age. One full-profile cut and four small trenches were made in each key site of pine forests under analysis to clarify the thickness of the genetic horizons: organogenic and podzolic. Samples of the ferruginous 
illuvial horizon from the small trenches were taken with a soil sampler with a nozzle for loose soils. The diagnostics and classification of soils was carried out in accordance with modern concepts of soil classification $[17,18]$.

The soil profile of key site 1 is represented by hydrometamorphosed urbanozem on Umbric Podzol, (figure. 1).

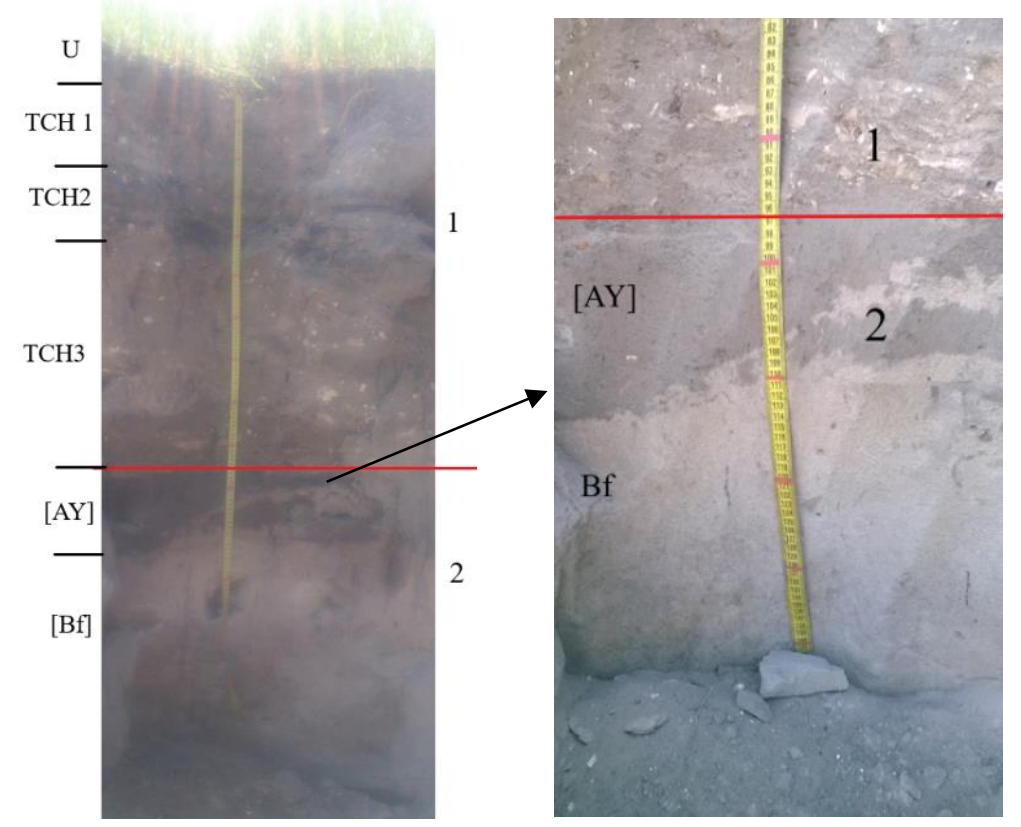

Fig.1. The profile of the buried Umbric Podzol - key site 1 (1.Technosols, 2. Umbric Podzol).

The surface horizon of urban soil is represented by an urbic horizon, transformed and decompressed by ruderal vegetation. In general, the technogenic part of the profile is $100 \mathrm{sm}$ high and is represented by alternating layers of carbonate loess loams with a large proportion of anthropogenic inclusions such as crushed stone and broken brick, lime, coal, wood waste. The layers are highly compacted and poorly aerated, for example, in the $\mathrm{TCH} 2$ horizon, progressive processes are visible for instance gleying on the surfaces of soil aggregates. The buried Umbric Podzol has a typical profile structure: AY - Bf - C. Horizon AY (100-116 sm) - color according to Munsell - 7.5YR 5/1, humid, sandy, amorphous, dense, there are manganese nodules and anthropogenic inclusions of glass fragments, the transition is sharp in color, does not boil; Bf (116-160 sm) - color according to Munsell - 7.5YR 8/4, moist, sandy, amorphous, loose, single humus tongues up to $20 \mathrm{sm}$ deep, mineral grains are covered with thin ferruginous coating, the transition is gradual in color, does not boil; C (160-200 sm) - color according to Munsell - 7.5YR 8/6, moist, sandy, amorphous, loose.

The soils of key sites 2 and 3 are represented by Carbic Podzols (Arenic) on fluvioglacial and ancient alluvial sandy deposits. The structure and morphology of soil profiles is shown in Figure 2. 
A

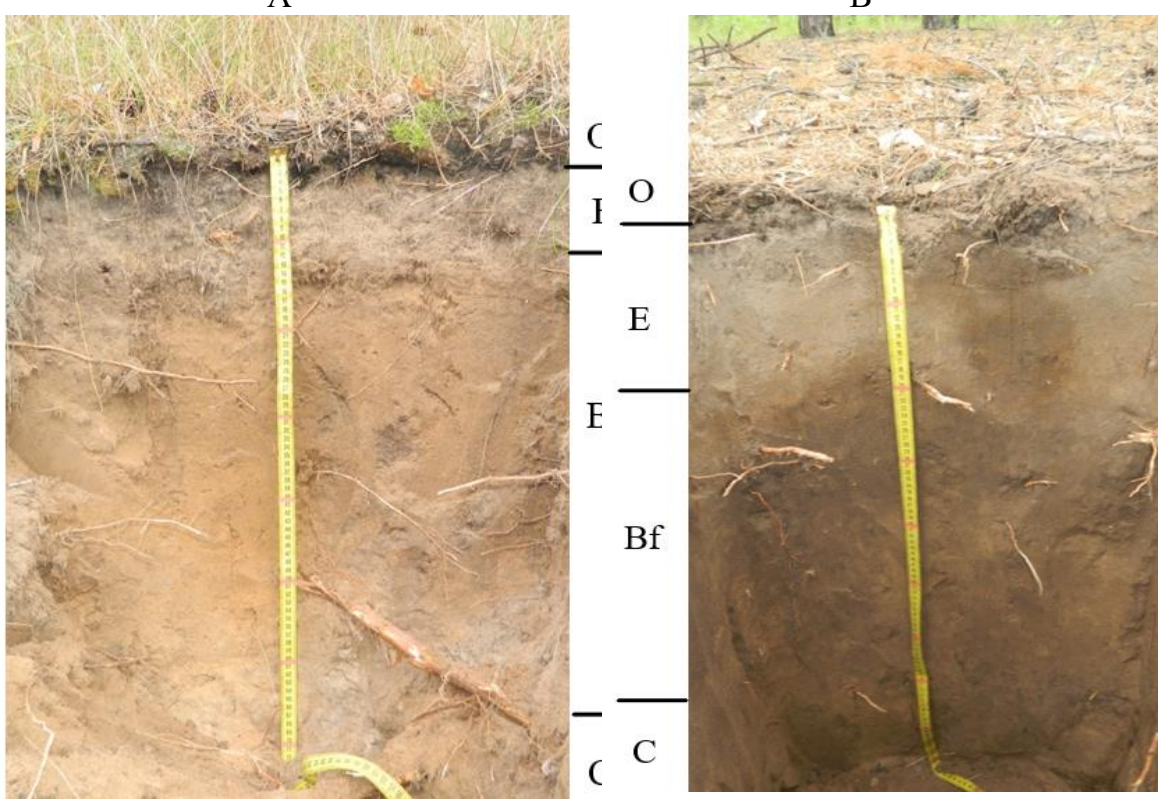

Fig.2. Soil profiles of Carbic Podzols (Arenic): A - key site 2, B - key site 3.

Carbic Podzol (Arenic) of key site 2 had the following characteristics: O (0-3) color according to Munsell - 10 YR 2/1 - organogenic horizon litter-peat horizon in the lower part there was an interlayer of dark coarse humus material; E (3-11 sm) color according to Munsell 7.5 YR 7/1, fresh, sandy, amorphous, loose, mineral grains completely without any coating, with lots of roots, clear transition in color; $\mathrm{Bf}(11-65 \mathrm{sm})$ color according to Munsell 7.5 YR 8/6, fresh, sandy, amorphous, loose, mineral grains covered with thin ferruginous coating, traces of illuviation $\mathrm{Fe}$ and $\mathrm{Al}$ in the form of adhesion, with lots of Scots pine roots, gradual color transition ; C (65 - $100 \mathrm{sm})$ color according to Munsell 7.5YR 7/6, moist, sandy, amorphous, loose, Scots pine roots.

Carbic Podzol (Arenic) of key site 3 in the forest stand of Dichnya had a profile similar to that of podzol of key site 1: O (0-3) color according to Munsell - 10 YR 2/1 - organogenic horizon litter-peat horizon in the lower part there was an interlayer of dark coarse humus material; E (3-16 sm) color according to Munsell 7.5 YR 8/1, dry, sandy, amorphous, loose, mineral grains without any coating, lots of roots, clear transition in color; $\mathrm{Bf}$ (16 - $58 \mathrm{sm})$ color according to Munsell 7.5 YR 4/2, moist, sandy, amorphous, loose, mineral grains covered with thin ferruginous coatig, traces of $\mathrm{Fe}$ and $\mathrm{Al}$ illuviation in the form of adhesion, Scots pine roots, gradual color transition; C (58 - $99 \mathrm{sm}$ ) color according to Munsell 7.5YR $4 / 4$, moist, sandy, amorphous, loose, manganese nodules $\mathrm{D}=5 \mathrm{~mm}$, Scots pine roots.

Soil samples in soil profiles were taken in conjunction with genetic horizons. Sampling was carried out in accordance with GOST 17.14.3.01-83, GOST 28168-89 and GOST 14.4.4.02-84. Using standard methods, the basic chemical and physicochemical characteristics were determined: organic matter according to Tyurin (GOST 26213-91) the content of humus (Tyurin's method, GOST 26213-91), pHKCl (GOST 26483-85) (KCl, State Standard (GOST) 26483 -85), hydrolytic acidity, easily hydrolyzable nitrogen (according to Cornfield) the content of nitrogen (Cornfield'smethod), mobile phosphorus (GOST 2620491), exchangeable potassium (GOST 26204-91) the available phosphorus (GOST 26204-91) and potassium (GOST 26204-91 ). Determination of mobile forms of heavy metals was carried out by atomic absorption spectroscopy. Sample preparation - mobile forms of HM were extracted by an extract of ammonium acetate buffer $\mathrm{pH}=4.8$ (RD 52.18.289-90). 
Statistical data processing was carried out using the analysis package of Microsoft Office 2010 (MicrosoftExel).

\section{Chemical and physical and chemical characteristics of sandy podzols in the chronosequence of Scots pine stands 0 - $70-100$ years}

The humus content in the humus-accumulative and podzolic horizons of the soils under analysis is comparable, that means that within 100 -years this indicator remained practically unchanged $(0.5-0.6 \%)$, but the qualitative composition of humus may have changed (the proportion of humic and fulvic acids). In the illuvial-ferruginous soil horizons of key areas during the 100-year vegetation of Scots pine, there was a gradual increase in the humus content in comparison with a similar horizon of buried sandy sod-podzol. This can be explained by soil acidification and a subsequent increase in the intensity of the vertical migration of dissolved organic matter. The duration of vegetation of pine stands on the studied soils significantly intensified this process (Table 1).

Table 1. Profile distribution of basic characteristics of sandy podzols in chronosequence $\ll 0-70-$ 100 years» under Scot pine plantations

\begin{tabular}{|c|c|c|c|c|c|}
\hline $\begin{array}{l}\text { Genetic } \\
\text { horizon }\end{array}$ & $\underset{\%}{\text { Humus, }}$ & pHкCl & $\begin{array}{c}\mathrm{P}_{2} \mathrm{O}_{5}, \\
\text { mobile., } \\
\text { ppm }\end{array}$ & $\begin{array}{c}\mathrm{K}_{2} \mathbf{0}, \\
\text { exchangeable., } \\
\text { ppm }\end{array}$ & $\begin{array}{c}\text { N alkaline } \\
\text { hydrolyzable, } \\
\text { mg/kg }\end{array}$ \\
\hline \multicolumn{6}{|c|}{ 1. Umbric Podzols, buried profile KZTZ plant (1954) zero-moment } \\
\hline [AY] & $0.5 \pm 0.1$ & $7.9 \pm 0.3$ & $338 \pm 7$ & $157 \pm 4$ & $48 \pm 2$ \\
\hline$[\mathrm{Bf}]$ & $0.1 \pm 0.1$ & $7.8 \pm 0.2$ & $105 \pm 4$ & $106 \pm 3$ & $26 \pm 1$ \\
\hline$[\mathrm{C}]$ & $0.1 \pm 0.1$ & $7.5 \pm 0.3$ & $110 \pm 5$ & $117 \pm 4$ & $11 \pm 1$ \\
\hline \multicolumn{6}{|c|}{ 2. Carbic Podzols (Arenic). Scots pine plantations, age 70 years } \\
\hline $\mathrm{O}$ & $0.8 \pm 0.2$ & $5.2 \pm 0.2$ & $28 \pm 2$ & $25 \pm 1$ & $28 \pm 1$ \\
\hline $\mathrm{E}$ & $0.5 \pm 0.1$ & $4.7 \pm 0.2$ & $22 \pm 1$ & $30 \pm 2$ & $28 \pm 2$ \\
\hline $\mathrm{Bf}$ & $0.2 \pm 0.1$ & $5.2 \pm 0.1$ & $33 \pm 3$ & $30 \pm 2$ & $25 \pm 2$ \\
\hline $\mathrm{C}$ & $0.1 \pm 0.01$ & $5.2 \pm 0.1$ & $95 \pm 5$ & $32 \pm 3$ & $12 \pm 1$ \\
\hline \multicolumn{6}{|c|}{ 3. Carbic Podzols (Arenic). Scots pine plantations, age 100 years } \\
\hline $\mathrm{O}$ & $1.1 \pm 0.2$ & $4.0 \pm 0.1$ & $128 \pm 4$ & $42 \pm 3$ & $45 \pm 1$ \\
\hline $\mathrm{E}$ & $0.6 \pm 0.1$ & $4.0 \pm 0.2$ & $111 \pm 5$ & $30 \pm 2$ & $28 \pm 3$ \\
\hline $\mathrm{Bf}$ & $0.3 \pm 0.1$ & $4.6 \pm 0.2$ & $163 \pm 8$ & $33 \pm 2$ & $21 \pm 2$ \\
\hline $\mathrm{C}$ & $0.2 \pm 0.1$ & $4.6 \pm 0.2$ & $266 \pm 11$ & $29 \pm 2$ & $14 \pm 1$ \\
\hline
\end{tabular}

Mineralization of needle litter during the 100-year succession period led to soil acidification. After 70 years of vegetation of Scot pines, the soils had soil reaction $\mathrm{pH} 4.7$ units (medium acid soils), and in the areas with a Scots pine stand of about 100 years old, the soils had a strongly acidic reaction - 4.0 units.

With regard to the elements of mineral nutrition of plants, a significant decrease in the content of mobile phosphorus, exchangeable potassium and easily hydrolyzed forms of nitrogen was noted at the stage of soil succession 0 - 70 years. In the period from 70 to 100 years, the organogenic and mineral soil horizons were enriched with mobile phosphorus. This may also be related to the spatial diversity of the chemical composition of fluvioglacial and ancient alluvial deposits. Exchangeable potassium and organic forms of nitrogen in this time 
interval were characterized by a relative increase in their content in the organogenic horizon of the Carbic Podzol (Arenic) in the area with a pine forest stand of 100 years. Podzolic and ferruginous illuvial horizons in key areas 2 and 3 had comparable values.

Monodominant plantations of Scots pine on Carbic Podzols (Arenic) led to impoverishment of horizons in the upper part of the profile $(\mathrm{O}, \mathrm{E})$ with such microelements: $\mathrm{Cu}, \mathrm{Zn}, \mathrm{Ni}, \mathrm{Mn}$, and $\mathrm{Co}$. This is clearly noticeable during the period of soil succession from 70 to 100 years (Table 2).

Table 2. Profile distribution of HMs in sandy podzols

in chronosequence $« 0-70-100$ years» under Scot pine plantations

\begin{tabular}{|c|c|c|c|c|c|c|c|}
\hline \multirow{2}{*}{$\begin{array}{l}\text { Genetic } \\
\text { horizon }\end{array}$} & \multicolumn{7}{|c|}{ Concentration of mobile forms of HMs, ppm } \\
\hline & $\mathbf{C u}$ & Zn & Mn & Co & $\mathbf{P b}$ & Cd & $\mathbf{N i}$ \\
\hline \multicolumn{8}{|c|}{ 1. Umbric Podzols, buried sod-podzol KZTZ plant (1954) zero-moment } \\
\hline$[\mathrm{AY}]$ & $0.2 \pm 0.03$ & $2.9 \pm 0.1$ & $2.8 \pm 0.2$ & $0.06 \pm 0.02$ & $2.2 \pm 0.1$ & $0.03 \pm 0.01$ & $0.5 \pm 0.1$ \\
\hline [Bf] & $0.1 \pm 0.04$ & $1.5 \pm 0.1$ & $0.1 \pm 0.1$ & $0.26 \pm 0.03$ & $1.0 \pm 0.2$ & $0.04 \pm 0,01$ & $0.4 \pm 0.1$ \\
\hline \multicolumn{8}{|c|}{ 2. Carbic Podzols (Arenic). Scots pine plantations, age 70 years } \\
\hline $\mathrm{O}$ & $0.4 \pm 0.02$ & $1.4 \pm 0.1$ & $6.9 \pm 0.3$ & $0.09 \pm 0.03$ & $2.7 \pm 0.3$ & $0.07 \pm 0.01$ & $0.7 \pm 0.1$ \\
\hline $\mathrm{E}$ & $0.2 \pm 0.03$ & $1.4 \pm 0.2$ & $11.4 \pm 0.5$ & $0.07 \pm 0.02$ & $1.1 \pm 0.2$ & $0.07 \pm 0.01$ & $0.7 \pm 0.1$ \\
\hline $\mathrm{Bf}$ & $0.3 \pm 0.01$ & $0.8 \pm 0.1$ & $0.6 \pm 0.3$ & $0.10 \pm 0.04$ & $0.9 \pm 0.2$ & $0.06 \pm 0.01$ & $0.6 \pm 0.2$ \\
\hline \multicolumn{8}{|c|}{ 3. Carbic Podzols (Arenic). Scots pine plantations, age 100 years } \\
\hline $\mathrm{O}$ & $0.2 \pm 0.04$ & $1.1 \pm 0.3$ & $8.2 \pm 0.3$ & $0.04 \pm 0.01$ & $1.3 \pm 0.2$ & $0.09 \pm 0.01$ & $0.3 \pm 0.1$ \\
\hline E & $0.1 \pm 0.02$ & $1.0 \pm 0.2$ & $7.6 \pm 0.4$ & $0.02 \pm 0.01$ & $0.8 \pm 0.1$ & $0.07 \pm 0.02$ & $0.2 \pm 0.1$ \\
\hline $\mathrm{Bf}$ & $0.1 \pm 0.02$ & $1.0 \pm 0.2$ & $0.6 \pm 0.2$ & $0.10 \pm 0.02$ & $0.8 \pm 0.1$ & $0.04 \pm 0.01$ & $0.3 \pm 0.1$ \\
\hline
\end{tabular}

The content of mobile forms of $\mathrm{Cu}$ in the podzol of key site 3 (100 years) decreased on average by $50 \%$ in relation to the podzol of key site 2 (70 years). The content of mobile forms of $\mathrm{Zn}$ also decreased by $21.4-28.5 \%, \mathrm{Ni}$ - by $57.1-71.4 \%$, Co - by $55.5-71.2 \%, \mathrm{Mn}-$ by $28.0 \%$. This is due to the intensification of the podzolization process, which contributed to the leaching of mobile forms of HM outside the soil profile. The impact of federal highways and the recreational load on the soils of key sites 2 and 3 led to a significant increase in $\mathrm{Pb}$ concentration (in 1.2 - 3.0 times) and $\mathrm{Cd}$ (4.0 - 9.0 times) in the genetic horizons of Carbic Podzols (Arenic), in relation to the background concentration values of these elements in soils and parent rock of Kursk region. Concentrations of mobile forms of $\mathrm{Cu}, \mathrm{Zn}, \mathrm{Ni}, \mathrm{Mn}, \mathrm{Co}$ were within the background values. No excess of MAC was revealed for all HMs that were analyzed.

\section{Direction and intensity of elementary soil processes in sandy podzols in condition of changed vegetation}

The formed plantations of Scots pine and their vegetation for 100 years led to the transformation of the original sandy illuvial-ferruginous sod-podzols. After the Scots pines had been planted, the podzolic process gradually began to prevail over the soddy one, which is confirmed by the appearance of a clearly pronounced podzolic horizon (E) in the soils of key sites 2 and 3 (Fig. 1). In the profile of the buried Umbric Podzol (key site 1), isolated podzolic horizon cannot be seen; the presence of a developed podzolic process was revealed based on the presence of skeletans in AY horizon. In the profiles of Carbic Podzols (Arenic) 
located in pine stands, isolated podzolic horizons with a thickness of 8-13 sm were identified (Table 3).

Table 3. Changes in elementary soil processes in the chronosequence 0 - 70 - 100 years under Scots pine plantations

\begin{tabular}{|c|c|c|c|}
\hline \multirow{2}{*}{ Diagnostic sign } & \multicolumn{3}{|c|}{ Key site of the soil chronosequence under analysis } \\
\cline { 2 - 4 } & $\begin{array}{c}\text { 1. Umbric } \\
\text { Podzols, buried } \\
\text { profile KZTZ plant } \\
(\mathbf{1 9 5 4}) \text { zero-moment }\end{array}$ & $\begin{array}{c}\text { 2. Carbic } \\
\text { Podzols (Arenic). } \\
\text { Scots pine } \\
\text { plantations, age 70 } \\
\text { years }\end{array}$ & $\begin{array}{c}\text { 3. Carbic } \\
\text { Podzols (Arenic). } \\
\text { Scots pine } \\
\text { plantations, age } \\
\text { 100 years }\end{array}$ \\
\hline $\begin{array}{c}\text { Depth of horizon } \\
\text { AY, sm }\end{array}$ & $17 \pm 3$ & 0 & 0 \\
\hline $\begin{array}{c}\text { Degradation rate of } \\
\text { the horizon AY, } \\
\text { sm/year }\end{array}$ & - & $0.26 \pm 0.03$ & $0.26 \pm 0.03$ \\
\hline $\begin{array}{c}\text { Depth of horizon } \\
\text { E, sm }\end{array}$ & 0 & $8 \pm 1$ & $13 \pm 2$ \\
\hline $\begin{array}{c}\text { Progression rate of } \\
\text { the horizon E, sm/year }\end{array}$ & - & $0.11 \pm 0.01$ & $0.17 \pm 0.02$ \\
\hline $\begin{array}{c}\text { Storage of organic } \\
\text { substance in soil } \\
\text { profile, tonne/hectar }\end{array}$ & $16.6 \pm 1.2$ & $17.2 \pm 2.3$ & $25.3 \pm 1.7$ \\
\hline
\end{tabular}

It is worth noting that during 70 years of functioning of monodominant plantations of Scots pine, there was a complete degradation of the humus-accumulative horizon (AY). The relative rate of degradation in the studied chronosequence was at average $0.26 \mathrm{sm} /$ year. The rate of development of the podzolic horizon averaged $0.11 \mathrm{sm} /$ year. The rate of development of the podzolic process depended on the age of Scots pine plantations. So in the period from 70 to 100 years, the intensity of soil podzolization increased by $54.5 \%$. The enrichment of the soil profile with humus, quite obviously, had an effect on the increase in the humus storage in the soil profile. This indicator in the time period of the soil succession of $70-100$ years increased by $47.1 \%$, which occurred not only due to the accumulation of humus, but also due to an increase in the total thickness of the soil profile.

The ecological efficiency of the practical use of monodominant plantations of Scots pine in the conditions of the Kursk region requires a more detailed study. It remains unclear whether such natural-anthropogenic landscapes will be able to solve the problems of forming the ecological sustainability of ecosystems, achieving a zero carbon balance, and preserving biological diversity.

\section{Conclusion}

Soil successions caused by anthropogenically formed monodominant plantations of Scots pine, in the time series $0-70-100$ years, led to the transformation of soils at the type level. During 100 years of vegetation of monodominant plantations of Scots pine in Kursk region, the following model of soil succession was revealed: Umbric Podzols $\rightarrow$ Carbic Podzols (Arenic). Soil succession goes along with degradation of the humus-accumulative horizon, strong acidification of soils and the gradual development of podzolic process. within the limits of $0.11-0.17 \mathrm{sm} /$ year. Within the chronoseries under analysis, in contrast to total increase in the vertical migration of substances, the lower part of the profile is enriched with humus with a general tendency to an increase in the humus reserve in the Carbic Podzols (Arenic) profile, but at the same time the content of macro- and microelements in all genetic horizons of the profile significantly decreases. 
The research was carried out with support of Grant of the President of the Russian Federation for Young Russian Scientists - Candidates of Sciences (Project - MK-416.2021.1.4).

\section{References}

1. I.I.Vasenev, Soil successions (Moscow: LCI, 2008)

2. T.V.Prokof'eva, M.I. Gerasimova, O.S. Bezuglova, S.N. Gorbov, K.A. Bakhmatova, N.N. Matinyan, A.A. Gol'evaE.A, E.A. Zharikova, E.N. Nakvasina, and N.E. Sivtseva, Eurasian soil science 47 (10), 959 (2014)

3. M.N. Stroganova, M.G. Agarkova, Eurasian soil science 7, 16 (1992)

4. T.V.Prokofyeva, I.A. Martynenko, F.A. Ivannikovб Eurasian soil science 44 (5), 561(2011)

5. N.E. Kosheleva, N.S. Kasimov, D.V. Vlasov, Eurasian soil science 48 (5), 476 (2015)

6. A.A.Vasiliev, A.N. Chashchin, Heavy metals in the soils of the city of Chusovoy: assessment and diagnostics of pollution (Perm: FGBOU VPO Perm State Agricultural Academy, 2011)

7. C.S.C. Wong, X. Li, I. Thornton, Environmental Pollution 142 (1), 1 (2006)

8. N. Nevedrov,South of Russia: ecology, development 4, 97 (2018)

9. M.I. Gerasimova, M.N. Stroganova, N.V. Mozharova, T.V. Prokofeva, Anthropogenous soils: genesis, geography, recultivation (Smolensk: Ojkumena Publ., 2003)

10. Y.N. Vodyanitskii, Eurasian soil science 43 (10), 1184 (2010)

11. N.P. Nevedrov, Journal of Ecology and Life Safety 27(3), 209 (2019)

12. E.A. Batrachenko, I.A. Goneev, O.P. Lukashova. I.Yu. Ozerova, Bulletin of the Samara Scientific Center of the Russian Academy of Sciences 16 (1), 607, (2014)

13. N.P. Nevedrov,E.P. Protsenko, E.V. Ivanova, AUDITORIUM Electronic scientific journal of Kursk State University 12 (4), 1 (2016)

14. A.V. Poluyanov, Flora of the Kursk region (Kursk: Kursk State University, 2005)

15. V.V. Dokuchaev, Selected works ed. prof. S.S. Sobolev (Moscow: Publishing House of Agricultural Sciences literature, 1954)

16. N.P. Remezov,Eurasian soil science 7,80 (1956)

17. L.L. Shishov, V.D. Tonkonogov, I.I. Lebedeva, M.I. Gerasimova, Classification and diagnostics of soils in Russia (Smolensk: Oikumena, 2004)

18. IUSS Working Group WRB. World Reference Base for Soil Resources, International soil classification system for naming soils and creating legends for soil maps. World Soil Resources Reports No 106 (Rome: FAO, 2014) 